\title{
Piotr Żmigrodzki, \\ Wprowadzenie do leksykografii polskiej, \\ Wydawnictwo Uniwersytetu Śląskiego, Katowice 2003, s. 269
}

Omawiana praca jest podręcznikiem akademickim, który, jak podkreśla autor w Przedmowie, pod względem zawartości i układu materiału jest zgodny z zaproponowaną wcześniej przez niego koncepcją leksykograficznego kształcenia studentów filologii polskiej. Żmigrodzki twierdzi, że leksykografii nie należy traktować jako dodatku do zajęć z leksykologii lub wstępu do językoznawstwa. „Leksykografia ma być kursem o celach przede wszystkim praktycznych, tzn. ma zapoznawać $z$ konwencjami opisu stosowanymi w słownikach języka polskiego oraz z dostępną współcześnie ofertą słowników, dając jednocześnie studentowi - niezależnie od tego, czym się będzie zajmował po opuszczeniu uczelni - uniwersalne i zobiektywizowane narzędzia oceny słowników" (s. 11).

Podręcznik P. Żmigrodzkiego, adresowany przede wszystkim do studentów polonistyki oraz innych kierunków filologicznych, składa się z następujących części: Przedmowa, 1. Przedmiot i zakres leksykografii, 2. Metodologiczne i teoretyczne podstawy współczesnej leksykografii, 3. Podstawowe elementy opisu leksykograficznego, 4. Dodatkowe czynniki wpływające na kształt słownika, 5. Z historii polskiej leksykografii, 6. Polska leksykografia współczesna, Aneks, Bibliografia, Indeks ważniejszych terminów.

Rozdziały pierwszy i drugi poświęcone zostały problematyce ogólnej i metodologicznej. Autor definiuje pojęcie leksykografii, zwraca uwagę na szereg podziałów słowników, przeprowadzonych według różnych kryteriów (np. ze względu na układ artykułów hasłowych wyróżnia się słowniki alfabetyczne: a fronte, a tergo; słowniki niealfabetyczne: gniazdowe, pojęciowe; ze względu na przeznaczenie słowniki popularne i naukowe; ze względu na formę utrwalenia słow- 
nika: słowniki tradycyjne (książkowe), słowniki elektroniczne (komputerowe). Omawia tradycyjne i komputerowe metody tworzenia prac leksykograficznych oraz współczesne teorie leksykograficzne, które wpłynęły na najnowszą polską leksykografię (teoria W. Doroszewskiego, koncepcja M. Grochowskiego, dyskusje metodologiczne lat osiemdziesiątych - Z. Saloni, S. Szpakowicz, M. Świdziński, D. Kopcińska, W. Lubaś, A. Bogusławski, koncepcja "słownika przyjaznego użytkownikowi” - H. Zgółkowa, T. Piotrowski).

W rozdziale trzecim autor ustala znaczenie terminów: wyraz, leksem, jednostka leksykalna, wprowadza pojęcia makrostruktury słownika (wzajemny układ jego artykułów hasłowych) i mikrostruktury słownika (wewnętrzna struktura artykułu hasłowego). Szczegółowo omawia makrostrukturę i czynniki wpływające na jej kształt (układ haseł, dobór haseł w słowniku, różne możliwości hasłowania tych samych faktów językowych, homonimia a siatka haseł w słownikach, hasła odsyłaczowe i odsyłanie w słowniku). Zdecydowanie więcej miejsca poświęca mikrostrukturze słownika, czyli wewnętrznej budowie artykułu hasłowego, który ma największy wpływ na charakter słownika i jego jakość. Analizuje kolejne składniki artykułu hasłowego (wyraz hasłowy, informacja gramatyczna, kwalifikatory, definicja, ilustracja materiałowa w haśle, związki frazeologiczne, informacje o wymowie, informacje o pochodzeniu wyrazów, informacje o obecności hasła w innych słownikach, informacja o możliwości dzielenia wyrazu, wskazówki poprawnościowe), porównuje ich wypełnienie $w$ różnych słownikach. $W$ rozdziale tym autor przekazuje uniwersalną wiedzę o strukturze słownika, którą użytkownik polszczyzny będzie mógł w przyszłości zastosować do dowolnej pracy leksykograficznej.

Rozdział czwarty dotyczy dodatkowych czynników wpływających na budowę i kształt dzieła leksykograficznego. W mniejszym stopniu należą do nich normatywizm i perswazyjność, w większym zaś - czynniki społeczno-kulturowe i ideologiczne.

W rozdziale piątym autor przedstawia zarys dziejów polskiej leksykografii od czasów najdawniejszych do połowy XX wieku. Wydziela trzy zasadnicze okresy historyczne i prezentuje powstałe w nich słowniki.

Żmigrodzki podkreśla, że dzieje naszej leksykografii są ściśle zwią- 
zane $\mathrm{z}$ leksykografią europejską, $\mathrm{z}$ postępem wiedzy językoznawczej oraz z ogólną sytuacją kulturalną kraju. „W okresach stagnacji, np. w czasach saskich, leksykografia również nie rozwijała się zbyt intensywnie. Słowniki 1 . połowy XVIII wieku są nieliczne, przeważały wówczas przedruki dzieł dawniejszych. $Z$ okresami intelektualnego fermentu, przemian kulturowych, intensywnych kontaktów międzynarodowych wiążą się z kolei zjawiska gwałtownego rozwoju słownikarstwa. Tak było w połowie wieku XVI, gdy na swoisty boom słownikowy wywarło wpływ również upowszechnienie druku, rozwój szkół, powstanie nowych ruchów wyznaniowych. Ożywienie intelektualne czasów oświecenia zaowocowało w kilkadziesiąt lat później oryginalnym dziełem Lindego, również dziełami Bandkiego i Osińskiego" (s. 149).

Najobszerniejszy, liczący dziewięćdziesiąt jeden stron, rozdział szósty poświęcony jest polskiej leksykografii współczesnej, w której autor wyodrębnia następujące przedziały czasowe:

1. okres mecenatu państwowego: od roku 1950 do przełomu lat 1991/1992, charakteryzujący się monopolizacją leksykografii - prawo wydawania słowników miały nieliczne wydawnictwa, np. PWN, Wiedza Powszechna, Ossolineum, niewielką liczbą tytułów, słabym dostępem użytkowników polszczyzny do słowników, przewagą słowników naukowych nad popularnymi, instytucjonalizacją leksykografii - autorami słowników byli zazwyczaj językoznawcy pracujący na uniwersytetach lub w PAN, dominacją koncepcji Witolda Doroszewskiego;

2. okres leksykografii komercyjnej: od przełomu1991/1992 do dziś, wyróżniający się rozpadem mecenatu państwowego, związanym $\mathrm{z}$ upadkiem wydawnictw państwowych lub ich przekształceniem się w wydawnictwa komercyjne, demonopolizacją rynku wydawniczego - nowe wydawnictwa, np. Wilga, Prószyński i S-ka, Świat Książki, zaczęły do swej oferty wprowadzać słowniki, bogactwem oferty słowników, przewagą słowników popularnych, zwiększeniem zasięgu oddziaływania słowników - nieograniczone nakłady, coraz niższe ceny.

Następnie autor omawia wybrane słowniki dostępne na rynku w czasie powstawania tej książki. Prezentuje prace leksykograficzne według najogólniej wyodrębnionych ich typów. 
W omówieniu poszczególnych prac więcej miejsca poświęca słownikom bogato reprezentowanym na rynku, przeznaczonym dla szerszych kręgów odbiorców, niż słownikom ściśle naukowym. Zamieszcza informacje o liczbie artykułów hasłowych, bogactwie uwzględnionego materiału językowego, makrostrukturze i mikrostrukturze słowników, stopniu ich przydatności dla współczesnego czytelnika. Określa także grupy odbiorców, „którym poszczególne leksykony mogą oddać najlepsze usługi" (s. 152). W charakterystykach stara się unikać recenzowania. Czasami przywołuje recenzje drukowane w czasopismach naukowych. Prace leksykograficzne mniej ważne tylko wymienia, czasami podaje krótką informację o ich autorze, dacie wydania i objętości. Pomija słowniki przekładowe i przeznaczone dla obcokrajowców.

Po rozdziale szóstym autor zamieścił Aneks, który jest zestawieniem (w formie tabeli) zawartości artykułów hasłowych w sześciu współczesnych słownikach ogólnych: w Słowniku jezzyka polskiego PAN pod redakcją W. Doroszewskiego (SJDP), w Małym słowniku języka polskiego (MSJP), w Słowniku języka polskiego PWN pod reakcją M. Szymczaka (SJPSz), w Słowniku współczesnego języka polskiego pod redakcją B. Dunaja (SJPDun), w Praktycznym słowniku wspótczesnej polszczyzny pod redakcją H. Zgółkowej (PSWS), w Innym słowniku języka polskiego pod redakcją M. Bańki (ISJP).

Znajdująca się po Aneksie Bibliografia składa się z dwóch części. Część pierwsza zawiera skrócone opisy bibliograficzne wszystkich słowników omówionych lub przywołanych w podręczniku. Część druga to wykaz cytowanych opracowań teoretycznych w porządku alfabetyczno-chronologicznym.

Umieszczony na końcu podręcznika Indeks zawiera sto osiem terminów użytych $\mathrm{w}$ omawianej pracy, np. mikrostruktura słownika, homonimia fleksyjna, konwersja leksykalna, słownik a fronte, stownik offline, tezaurus.

Prezentowana praca jest pierwszym podręcznikiem leksykografii polskiej, uwzględniającym nową rzeczywistość po 1989 roku. Dzięki przemianom społeczno-politycznym powstał wolny rynek, nowy sektor bankowy, pojawił się kapitał zagraniczny. Została zniesiona cenzura. Upowszechniły się światowe zdobycze cywilizacyjne, zwłaszcza zasto- 
sowanie komputerów prawie we wszystkich dziedzinach życia ${ }^{1}$. Wszystkie te czynniki przyczyniły się do szybkiego rozwoju polskiego słownikarstwa. W związku z uwolnieniem rynku wydawniczego oraz automatyzacją gromadzenia materiału i opracowywania gotowych haseł, gwałtownie wzrosła liczba wydawanych prac. Tworzenie słowników stało się działalnością nastawioną przede wszystkim na zysk. „Użytkownik słownika nie tylko obcuje $\mathrm{z}$ wytworem działań intelektualno-warsztatowych pewnej osoby lub grupy osób, ale - zwłaszcza będąc nabywcą - wciela się w określoną rolę w grze rynkowej, w jaką dzieła leksykograficzne są włączone na równi z innymi publikacjami" (s. 12-13). $\mathrm{Z}$ tego względu pojawiła się ogromna potrzeba napisania podręcznika kształcącego „użytkowników słowników, tak aby nie tylko nabyli umiejętność efektywnego posługiwania się słownikiem (odczytania zawartych $w$ nim informacji), ale również zyskali orientację na leksykograficznym rynku wydawniczym, zdolność wyboru - spośród wielu pozornie podobnych - słownika odpowiedniego do indywidualnych potrzeb" (s. 12). Podręcznik Wprowadzenie do leksykografii polskiej spełnia to zadanie edukacyjne.

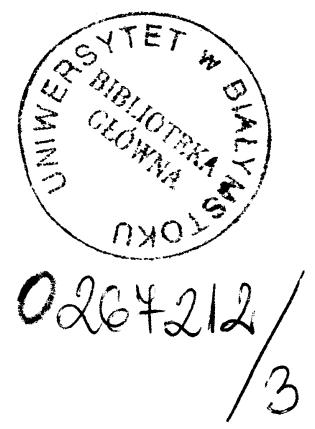

Katarzyna Kietlińska

1 K. Mosiołek-Kłosińska, Ślady polskich przemian po roku 1989 w słownictwie ogólnym, [w:] Polszczyzna w komunikowaniu publicznym, pod red. W. Gruszczyńskiego, J. Bralczyka, G. Majkowskiej, Warszawa 1999, s. 37. 